\title{
Миссия астронома Делиль де ла Кроера на Кольском п-ове и его сообщение о землетрясении 1728 г.
}

Никонов А.А., Флейфель Л.Д.

ИФ3 РАН, Москва, nikonov@ifz.ru

Аннотация. В сообщении анализируется первое и единственное письменное свидетельство о землетрясении 1728 г. на Кольском п-ове. Выявление достаточно сильного землетрясения с эпицентральной областью в пределах крупной Имандровской впадины - факт очень важный, поскольку за период не менее 300 лет сколько-нибудь значимые сейсмические события в районе не фиксировались, и только в период инструментальных наблюдений зарегистрировано несколько локальных толчков с незначительной магнитудой. Вновь вводимое в оборот событие 1728 г., несмотря на недостаточность сведений для точного определения его параметров, заставляет предпринять изменения оценок сейсмического потенциала района.

Ключевые слова: Кольский полуостров, Делиль де ла Кроер, сейсмический потенциал, исторические землетрясения.

\section{The mission of the astronomer Delil de la Croere on the Kola Peninsula and his report on the 1728 earthquake}

\author{
Nikonov A.A., Fleyfel L.D. \\ IPERAS, Moscow,nikonov@ifz.ru
}

Abstract. The paper analyzes the first and only written evidence of the 1728 earthquake on the Kola Peninsula. The identification of such a serious earthquake with an epicentral region within the large Imandrovskaya Depression is a very significant fact, since no significant seismic events were recorded in the region for at least 300 years, and only a few local tremors with insignificant magnitude were recorded only during instrumental observations. The newly introduced event of 1728, despite the insufficient information to accurately determine its parameters, forces changes in the estimates of the seismic potential of the region.

Key words: Kola Peninsula, Delille de la Croer, seismic potential, historical earthquakes.

\section{Краткие биографические сведения о Делиле де ла Кроере}

Имя французского астронома Людовика Делиль де ла Кроера в России известно слабо, даже в кругах академических. По поручению Российской Академии наук он производил астрономические и географические наблюдения в Архангельске и на Кольском полуострове в 1727-1729 гг. О его первой экспедиции, на Кольский п-ов, дошли лишь скупые сведения, поскольку его дневники не публиковались. А его сообщение о землетрясении на Кольском п-ове в 1728 г., лишь упоминалось. Между тем, оно имеет важное значение, и как первое, о котором на Кольском п-ове получены сведения, и поскольку за последующие почти 300 лет о подобных по месту и силе событиях неизвестно.

Упоминания разными исследователями землетрясения 1728 г. со ссылкой на Делиля

В середине XX в. о землетрясении 1728 г. «в Коле и Кандалакше» по наблюдениям Делиля стало известно по публикации Б.И. Петровского (Петровский, 1940), на которую ссылались сейсмологи (Горшков, 1947; Панасенко, 1969), сообщение содержит две фразы: «Первое известное нам землетрясение на Кольском полуострове отметил в своем дневнике французский астроном - профессор Людовик Делиль-де-ла-Кройер в 1728 году. Это землетрясение, очевидно, было неизвестно выдающемуся русскому геологу И.В. Мушкетову (1850-1902 гг.)». Действительно, в каталоге И.В. Мушкетова и А.П. Орлова (1893) событие не отражено. Отсутствует оно и в современных каталогах (Renquist, 1931; Новый ..., 1977; Shebalin, Leydecker, 1997; Землетрясения ..., 2007; Специализированный..., FENCAT). 


\section{Делиль на Кольском п-ове и его сведения о землетрясении в дневнике}

Письменное свидетельство о его экспедиции опубликовано только в XX-м веке: «Пробыв в экспедиции три года, де ла Кройер дважды совершал рейс от Архангельска к о. Кильдину и в Колу, пересекши Кольский полуостров по р. Туломе и пройдя затем в Кандалакшу, Ковду и Кереть... В Петербурге в декабре 1730 г. он представил в Конференцию дневники своего путешествия, из которых его братом были напечатаны астрономические и барометрические наблюдения. В целом виде его дневники напечатаны не были» (Экспедиции...., 1940). Запись о землетрясении сделана в конце его дневника, когда он вернулся из Колы в Архангельск по завершении работы, во 2-й тетради (Journal..., 1737).

Текст о землетрясении в переводе публикуется впервые.

«К концу августа 1728 г. в г. Коле было слабо ощущавшееся и непродолжительное землетрясение, замеченное некоторыми людьми и среди них господином М.В. Вернезобром, и некоторыми людьми в их домах. Оно не было замечено в той части города, которая непосредственно противостоит западному берегу (реки Колы), что могло быть из-за невнимательности ее обитателей, поскольку сообщают, что в Кандалакше оно испытано как более сильное (но? и?) (относительно?) продолжительное» [перевод К.И. Никоновой].

Здесь, наконец, мы узнаем, хотя и в предельно кратком изложении, реальные сведения о событии - конец августа, два удаленных друг от друга пункта с несколько различной силой. Это очень мало, но дает возможность обдумывать и наращивать варианты толкования. Астроном с помощниками дважды выезжал в Колу из г. Архангельска и оттуда совершил поездку на юг в Кандалакшу, затем далее вдоль Карельского берега через Ковду до Керети. Очень важно, что сведения исходят из двух пунктов Кола и Кандалакша, где он сам побывал и где было русское население. В Ковде и Керети, т.е. южнее Кольского п-ва, он таких сведений не получил. В конце августа и до середины ноября 1728 г. Делиль находился и вел наблюдения, в основном за полярными сияниями, на острове Кильдин, расположенном на расстоянии 70 км к северо-востоку от г. Кола. В его дневнике, в частности, отмечены даты астрономических наблюдений 27 августа, 1 сентября, 21 сентября и далее. Не приходится сомневаться в том, что землетрясение «к концу августа» на острове Кильдин им не ощущалось. Тот факт, что два с половиной месяца спустя, в Коле, ему о таковом сообщили, хотя подобные явления не входили в перечень поручений ему и его интересов, говорит о том, что для Колы оно стало событием памятным. И, вероятно, вспоминая перед отъездом из г. Архангельска о своих работах и полученных сведениях, он вспомнил и рассказ образованного иностранца господина Вернезобра о землетрясении.

Землетрясение ощущалось одновременно в 2-х, в то время единственных с постоянным русским населением, населенных пунктах Кола и Кандалакша на расстоянии около 200 км. В г. Кола сотрясение было одиночное, в то время, когда жители не спали. Ощущалось в домах и, по-видимому, на открытом воздухе. О колебаниях и опрокидывании предметов в домах не сообщалось. При оценке интенсивности надо учитывать, что дома были основательные, бревенчатые с угловыми соединениями в лапу, т.е. по макросейсмической шкале типа В. Основная часть города (с крепостью) располагалась на левом берегу р. Кола, в ее устье, на низкой морской террасе в вершине Кольского залива. Важно, что в Кандалакше сотрясения были несколько сильнее и продолжительнее, т.е. ближе к эпицентру.

Сотрясения в пунктах оцениваются как примерно IV-V балльные, эпицентральную область, где они должны были ощущаться гораздо сильнее, естественно помещать в центре Кольского п-ова, где в ту пору обитали только кочующие лопари. Сила сотрясений тут, скорее всего, оценивается не менее VII баллов.

\section{Заключение}

Выявление столь сильного землетрясения с эпицентральной областью в пределах крупной Имандровской впадины - факт очень значимый, и в познании сейсмических закономерностей, и в прикладном отношении. До сего дня в этой области не фиксировались за период не менее 300 лет 
сколько-нибудь значимые сейсмические события, и только в период инструментальных наблюдений зарегистрировано несколько локальных толчков с незначительной магнитудой. Вновь вводимое в оборот событие 1728 г., несмотря на недостаточность сведений для точного определения его параметров, заставляет поднять оценки сейсмического потенциала района до значений опасных в долговременном аспекте. Сам же район не просто освоенный в пределах Мурманской области, но выделен как горно-промышленный и научный кластер Заполярья с перспективой активного развития, что и определяет значимость новых данных.

Работа выполнена в рамках темы госзадания ИФЗ РАН.

\section{Литература}

1. Горшков Г.П. О сейсмичности Восточной части Балтийского щита // Тр. Сейсмологического института АН СССР. М. 1947. № 119. С. 12.

2. Землетрясения и микросейсмичность в задачах современной геодинамики Восточно-Европейской платформы. Кн. 1. Землетрясения. Петрозаводск. Изд-во: Карельский научный центр РАН. 2007. 381 стр.

3. Мушкетов И.В., Орлов А.П. Каталог землетрясений Российской Империи. СПб. 1893. 582 с.

4. Новый каталог сильных землетрясений на территории СССР. М. Изд-во: Наука. 1977. 536 с.

5. Панасенко Г.Д. Сейсмические особенности Северо-Востока Балтийского щита. Л. 1969. 183 с.

6. Петровский Б.И. Землетрясения на Кольском полуострове // Вестник знания. 1940. № 7. С. 8.

7. Специализированный каталог землетрясений для задач общего сейсмического районирования территории Российской Федерации. Редакторы В.И. Уломов, Н.С. Медведева. http://seismos-u.ifz.ru/documents/ Eartquake-Catalog. Интернет-ресурс, дата обращения 10.01.2020.

8. Экспедиции Академии наук XVIII-XIX веков. М.-Л. 1940. С. 35.

9. FENCAT https://www.seismo.helsinki.fi/EQ-search/query.php. Интернет-ресурс, дата обращения 10.01.2020.

10. Journal du Voyage fail par L. De Lisle de la Croyere dans les parties Septentrionalles de la Russie. СПб филиал Архива РАН, Р. І. Оп. 50. № 2, 3. Л. С. 260-261.

11. Renguist H. Finlands jordskalv // Fennia. 1931. V. 54. № 1. P. 1-113.

12. Shebalin N.V., Leydecker G. Earthquake Catalogue for the Former Soviet Union and Borders up to 1988. Office for Official Publications of the European Communities, Luxembourg. 1997. 135 p. 